\title{
PENGARUH SUHU ANAEROBIK TERHADAP HASIL BIOGAS MENGGUNAKAN BAHAN BAKU LIMBAH KOLAM IKAN GURAME
}

\author{
Dwi Irawan ${ }^{1)}$, Ahmad Khudori. ${ }^{2)}$ \\ Program Studi Teknik Mesin, Fakultas Teknik, Universitas Muhammadiyah Metro., ${ }^{1,2)}$ \\ Jl. Ki Hajar Dewantara 15 A Metro, Lampung. \\ dwi_irawan12@yahoo.co.id
}

\begin{abstract}
ABSTRAK
Semakin menipisnya cadangan bahan bakar fosil sebagai sumber energi bertolak belakang terhadap peningkatan kebutuhan energi seiring pertumbuhan populasi manusia, khususnya di Indonesia. Hal ini merupakan dasar perlunya pengembangan energi terbarukan sebagai upaya mengatasi berbagai permasalahan terhadap penggunaan energi fosil dan dampaknya pada lingkungan. Biogas sebagai energi terbarukan yang ramah lingkungan dapat menjadi salah satu solusi terhadap permasalah energi saat ini. Penelitian ini bertujuan untuk mengetahui pemanfaatan dan pengaruh suhu Anaerobik terhadap produksi biogas dengan menggunakan bahan baku limbah kolam ikan gurame. Perlakuan yang digunakan dalam penelitian ini adalah subtrat tanpa perlakuan suhu (T1), subtrat pada kondisi suhu mesofilik $35^{\circ} \mathrm{C}$ (T2) dan subtrat kondisi suhu termofilik $55^{\circ} \mathrm{C}$ (T3) pada 8 liter subtrat dalam digester. Hasil penelitian menunjukkan, perlakuan T1 mendapatkan volume akumulasi biogas $11.210 \mathrm{ml}$, laju aliran 448,4 ml/hari dan potensi biogas 1.401,25 $\mathrm{ml} /$ liter bahan baku, sedangkan untuk perlakuan T2 volume akumulasi biogas sebesar $19.370 \mathrm{ml}$, laju aliran 774,8 $\mathrm{ml} /$ hari dan potensi biogas $2.421,25 \mathrm{ml} /$ liter bahan baku serta perlakuan T3 mendapatkan volume akumulasi biogas $4.210 \mathrm{ml}$, laju aliran 168,4 ml/hari dan potensi biogas $520 \mathrm{ml} /$ liter bahan baku dengan tekanan yang sama pada semua perlakuan yaitu $101.570,25 \mathrm{~N} / \mathrm{m}^{2}$. Uji nyala menunjukkan hasil nyala api biru biogas yang dihasilkan dari semua perlakuan. Hasil penelitian menunjukkan perlakuan suhu Anaerobik berpengaruh terhadap hasil biogas. Dari hasil semua perlakuan kondisi yang paling baik adalah pada kondisi suhu mesofilik dengan penggunaan suhu $35^{\circ} \mathrm{C}$.
\end{abstract}

Kata Kunci : Biogas, Ikan Gurame, suhu, dan kondisi Mesofilik.

\section{PENDAHULUAN}

Biogas sebagai sumber energi alternatif yang proses produksinya dapat dilakukan dengan berbagai limbah organik, merupakan salah satu jawaban dari masalah energi yang saat ini masih sangat bergantung dari sumber energi dari bahan bakar fosil. Sumber energi yang berasal dari bahan bakar fosil, seperti batu bara, minyak bumi dan gas alam memerlukan waktu jutaan tahun dalam proses pembentukannya, sehingga dapat dikatakan bahan bakar fosil merupakan bahan bakar tidak terbarukan. Biogas yang dihasilkan dengan memanfatkan limbah peternakan akan mendatangkan nilai lebih. Pengelolaan limbah yang dilakukan dengan baik selain dapat mencegah terjadinya pencemaran lingkungan juga memberikan nilai tambah terhadap usaha ternak (Kaharudin dan Farida, 2010).

Gas metana $\left(\mathrm{CH}_{4}\right)$ dan karbondioksida $\left(\mathrm{CO}_{2}\right)$ merupakan senyawa utama penyusun biogas. Biogas merupakan gas produk akhir dari proses degradasi anaerobik oleh bakteri-bakteri methanogen. Biogas merupakan bioenergi karena dapat dihasilkan dari biomassa. Sedangkan biomassa adalah materi organik yang berusian relatif muda yang berasal dari mahluk hidup atau produk dan limbah industri budidaya (peternakan, perkebunan, pertanian, kehutanan dan perikanan) (Waskito, 2011).

Potensi limbah perikanan banyak ditemukan di daerah sentra pembesaran perikanan terutama yang menggunakan media kolam beton, karpet dan terpal. Sedangkan di Indonesia banyak daerah yang menjadi sentra usaha perikanan yang limbahnya belum dimanfaatkan. Pada umumnya pembuangan limbah kolam akan dilakukan duatiga minggu sekali dengan membuang air pada bagian dasar yang merupakan limbah yang berasal dari kotoran ikan (feses) dan sisa pakan. Jika kotoran berbentuk lumpur pekat ini tidak segera dibersihkan maka kadar amoniak dalam air kolam akan meningkat dan dapat mengancam kelangsungan hidup ikan-ikan yang dipelihara (Sani, 2014).

Suhu merupakan salah satu parameter yang berpengaruh pada proses dekomposi anaerob bahan organik dan produksi gas. Peningkatan suhu dimaksudkan untuk mempercepat laju perombakan, sehingga menghasilkan gas lebih 
optimal dan proses perombakan lebih efisien ( Lusk dalam Indarto, 2010).

Penelitian dilakukan untuk mengetahui efektifitas dari pengolahan limbah kolam pembesaran ikan gurame dalam membentuk energi alternatif (biogas) maka dilakukan penelitian tentang proses pembentukan biogas dari limbah kolam ikan gurame melalui peningkatan suhu pada digester anaerob. Kondisi suhu yang kami gunakan adalah pertama tidak mengunakan perlakuan suhu. Yang kedua perlakuan pada kondisi suhu mesofilik dan pada kondisi suhu termofilik.

\section{LANDASAN TEORI \\ Biogas}

Biogas merupakan campuran antara gas-gas yang dihasilkan dari proses penguraian anaerob (tanpa udara) atau fermentasi dari material organik seperti kotoran hewan, lumpur kotoran, sampah padat atau sampah terurai. Biogas dapat dihasilkan pada hari ke 4-5 sesudah digester terisi penuh dan mencapai puncaknya pada hari ke 2025 (Wahyono dan Sudarno, 2012). Dalam proses pembuatan biogas, sumber bahan baku atau limbah yang digunakan akan mempengaruhi kualitas dan kuantitas biogas yang dihasilkan (Werner et. al dalam Indarto, 2010). Proses dekomposisi anaerobik dibantu oleh sejumlah mikroorganisme, terutama bakteri metanogen.

Dalam (Suriawiria, 2003) menyebutkan terdapat tiga kelompok bakteri yang berperan dalam proses pembentukan biogas, yaitu:

1. Kelompok bakteri fermentatif: Steptococci, Bacteriodes, dan beberapa jenis Enterobactericeae

2. Kelompok bakteri asetogenik: Methanobacillus, Desulfovibrio dan sebagainya

3. Kelompok bakteri metana: Mathanobacterium, Mathanobacillus, Methanosacaria, dan Methanococcus.

Menurut catatan LIPI, Indonesia memiliki potensi biogas sebesar 685 Megawatt dan baru $1 \%$ yang dimanfaatkan. Potensi ekonomis biogas sangat besar, karena biogas dengan kandungan gas metana 65-70 \% setara dengan 5200-5900 $\mathrm{kkal} / \mathrm{m}^{3}$ energi panas dan setara dengan $1,25 \mathrm{kWh}$ listrik (Veziroglu dan De Baier, dalam Indarto, 2010). Selain itu, biogas sebagai sumber energi tidak mencemari lingkungan seperti minyak dan gas bumi. Oleh karena itu, sudah saatnya pemerintah mendukung program yang dapat memaksimalkan pemanfaatan potensi biogas di Indonesia melalui berbagai program. Pemerintah dapat belajar dari Negara Cina yang mendorong biometanasi skala kecil yang menggunakan bahan baku limbah hewan dan pertanian. Hingga tahun 2006, sekitar 20 juta keluarga di Daerah Cina menggunakan biometana untuk memasak dan penerangan (Kementerian Pertanian, Kehutanan dan Perikanan, 2008).

Kandungan utama dari biogas adalah gas metana $\left(\mathrm{CH}_{4}\right) 54-70 \%$, karbondioksida $\left(\mathrm{CO}_{2}\right) 27$ $35 \%$, karbon monoksida $(\mathrm{CO}) 0,1 \%$, oksigen $\left(\mathrm{O}_{2}\right)$ $0,1 \%$, nitrogen $(\mathrm{N})$, hidrogen $\left(\mathrm{H}_{2}\right)$ dan hidrogen sulfida $\left(\mathrm{H}_{2} \mathrm{~S}\right)$ (Wahyono dan Sudarno, 2012).

\section{Perombakan Anaerob}

Perombakan anaerob merupakan suatu proses dekomposi/ pembusukan material organik yang prosesnya dilakukan oleh bakteri anaerobik dalam keadaan tanpa oksigen yang menghasilkan biogas dan limbah cair. Pada umumnya terdapat dua jenis perombakan anaerobik, yaitu alami dan buatan seperti terlihat pada gambar 1 dibawah ini

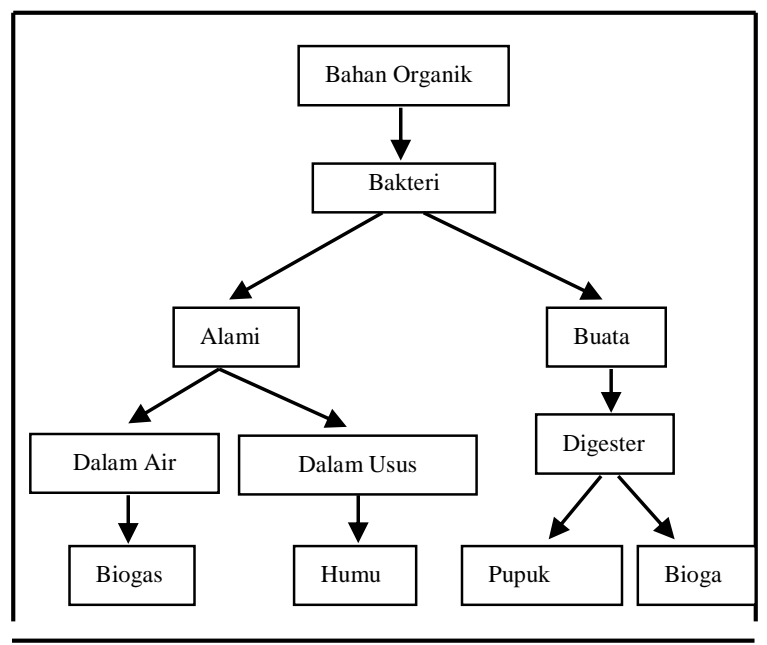

Gambar 1. Proses Pencernaan Anaerobik

Mikroorganisme anaerob menggunakan energi dengan memetabolisme bahan organik yang terdapat dalam bahan organik di dalam digester yang pada akhirnya menghasilkan biogas. Pada proses perombakan anaerob terjadi empat tahap proses transformasi pada bahan organik ( Lettinga dalam Indarto, 2010), yaitu:

1. Tahap hidrolisis

Pada tahapan hidrolisis, mikroba hidrolitik mendegradasi senyawa organik kompleks yang berupa polimer menjadi monomernya yang berupa senyawa tidak 
terlarut dengan berat molekul yang lebih ringan

2. Tahap asidogenesis

Monomer-monomer hasil hidrolisis dikonversi menjadi senyawa organik sederhana seperti asam lemak volatil, alkohol, asam laktat, senyawa mineral seperti karbondioksida, hidrogen, amoniak, dan gas hidrogen sulfida.

3. Asetogenesis

Hasil asidogenesis dikonversi menjadi hasil akhir bagi produksi metana berupa asetat, hidrogen, dan karbondioksida. Sekitar $70 \%$ dari COD semula diubah menjadi asam asetat.

\section{Metanogenesis}

Pada tahap metanogenesis, terbentuk metana dan karbondioksida. Metana dihasilkan dari asetat atau dari reduksi karbondioksida oleh bakteri asetotropik dan hidrogenotropik dengan menggunakan hydrogen.

\section{Limbah Kolam Pembesaran Ikan}

Pada budidaya perikanan khususnya pada sistem budidaya kolam dengan media terpal, beton dan plastik, salah satu aktivitas yang tidak boleh ditinggalkan adalah proses pembersihan lumpur di dasar kolam (shiphon). Pada dasarnya limbah ini menyerupai lumpur yang berwarna cokelat tua atau cokelat kehitam-hitaman yang terbentuk dari akumulasi kotoran ikan (feses) dan sisa pakan yang tidak termakan oleh ikan, lumpur ini yang disebut sebagai limbah kolam pembesaran ikan. Secara berkala limbah kolam harus dibersihkan karena merupakan sumber terbentuknya gas-gas yang sifatnya beracun dan dapat mengakibatkan kematian massal pada ikan yang dibudidayakan (Rahayu dan Masirah, 2014).

\section{Suhu atau Temperatur}

Pada umumnya terdapat dua kondisi suhu pada proses fermentasi anaerobik, yaitu pada kondisi suhu mesofilik dan kondisi suhu termofilik. Pada kondisi suhu mesofilik, suhu bekerja pada kisaran $28-45^{\circ} \mathrm{C}$ dengan kondisi suhu optimum $35-45^{\circ} \mathrm{C}$ sedangkan pada kondisi termofilik suhu bekerja pada kisaran $50-60^{\circ} \mathrm{C}$. Suhu optimal untuk mikroorganisme mesofilik adalah pada angka $35^{\circ} \mathrm{C}$, sedangkan untuk mikroorganisme termofilik adalah pada suhu $55^{\circ} \mathrm{C}$. Menurut (Sahirman dalam Indarto, 2010) rentan suhu optimal untuk digester di Indonesia adalah pada kisaran $35^{\circ} \mathrm{C}$. Oleh karena itu perlu pertimbangan dalam pembuatan digester anaerobik karena pada suhu dingin biasanya bakteri lebih lambat berproses sehingga biogas yang dihasilkan mungkin lebih lama (Wahyono dan Sudarno, 2012).

Sedangkan (Waskito,2010) menjelaskan bahwa ada 3 kondisi suhu pada proses pencernaan anaerobik yaitu:

1. Kondisi psikoprilik

Pada kondisi ini suhu digester bekerja pada rentan $10-18^{\circ} \mathrm{C}$ dan limbah/ sampah cair terdigestifikasi selama 30 - 52 hari.

2. Kondisi mesofilik

Pada kondisi mesofilik suhu digester bekerja pada rentan suhu $20-45^{\circ} \mathrm{C}$, dan sampah/ limbah cair terdigestifikasi selama 18 - 28 hari. Dibandingkan dengan kondisi termofilik, digester pada kondisi mesofilik pengoperasiannya lebih mudah tetapi biogas yang dihasilkan lebih sedikit dan volume digester lebih besar.

3. Kondisi termofilik

Pada kondisi termofilik digester bekerja pada rentan suhu $50-70^{\circ} \mathrm{C}$ dan limbah terdigestifikasi selama $11-17$ hari. Pada kondisi ini biogas yang dihasilkan lebih banyak, tetapi pengoperasiannya rumit dan mahal.

\section{Persamaan dalam Pembentukan Biogas}

Persamaan yang dapat digunakan dalam menentukan proses pembentukan biogas dari proses fermentasi limbah pada digester anerobik adalah sebagai berikut:

1. Persamaan tekanan biogas

Pada percobaan skala laboratorium, tekanan biogas yang dihasilkan dapat dihitung dengan melihat data pada manometer $U$ dan menggunakan data tersebut pada persamaan dibawah ini.

$$
P_{\text {gas }}=P_{\text {atm }}+\rho g h(\text { Joaquim, 2011) }
$$

$$
\begin{aligned}
& \text { Keterangan: } \\
& P_{g} \quad=\text { Tekanan Biogas }\left(\mathrm{N} / \mathrm{m}^{2}\right) \\
& P_{\text {atm }}=\text { Tekanan udara luar }\left(101.325 \mathrm{~N} / \mathrm{m}^{2}\right) \\
& \rho \quad=\text { Masa Jenis air }\left(1.000 \mathrm{~kg} / \mathrm{m}^{3}\right) \\
& \mathrm{g} \quad=\text { Gravitasi }\left(9,81 \mathrm{~m} / \mathrm{s}^{2}\right) \\
& \mathrm{h} \quad=\text { Perbedaan tinggi air }(\mathrm{m})
\end{aligned}
$$

2. Laju aliran produksi biogas perhari 
Laju aliran produksi perhari biogas yang dihasilkan dari proses fermentasi anaerob limbah kolam pembesaran ikan gurame merupakan rata-rata hasil biogas yang diproduksi dari subtrat dalam digester selama 25 hari waktu fermentasi. Sehingga untuk mencari laju aliran biogas harian dapat diketahui dengan persamaan sebagai berikut.

$V_{\text {rata-rata harian }}=\frac{V_{\text {total }}}{t}$

Keterangan:

$V_{\text {rata-rata }}=$ Laju aliran biogas perhari $(\mathrm{ml} /$ hari $)$

$V_{\text {total }} \quad=$ Volume total biogas $(\mathrm{ml})$

$t=$ Lama waktu fermentasi (hari)

3. Potensi biogas limbah kolam pembesaran ikan gurame

Potensi biogas dapat dianalisa dengan melakukan perhitungan matematis yaitu dengan membagi volume total akumulasi biogas yang diproduksi dibagi dengan jumlah volume subtrat dalam digester. Persamaan untuk potensi biogas limbah kolam pembesaran ikan gurame dapat dituliskan sebagai berikut.

$P_{\text {biogas }}=\frac{V_{\text {total biogas }}}{V_{\text {total subtrat }}}$

Keterangan:

$P_{\text {biogas }}=$ Potensi biogas $(\mathrm{ml} / \mathrm{l}$ bahan baku $(B B))$

$V_{\text {total biogas }}=$ Volume biogas total $(\mathrm{ml})$

$V_{\text {total subrat }}=$ Volume subtrat (liter)

4. Hasil biogas

Biogas yang dihasilkan akan dianalisa dengan metode Water displecement technique yang merupakan aplikasi dari Hukum Dalton Tentang Tekanan Gas Parsial. Hukum tekanan gas parsial menyatakan tekanan total campuran gas adalah penjumlahan dari tekanan - tekanan parsial gas - gas individu yang menyusun campuran gas tersebut (Chang, 1990). Dalam skala laboratorium, Hukum Dalton dapat digunakan untuk menghitung volume gas yang dikumpulkan dalam suatu reaksi dengan menggunakan bantuan air.

\section{METODE PENELITIAN}

Penelitian ini dilakukan di Laboratorium

Teknik Mesin Fakultas Teknik Universitas Muhammadiyah Metro.

Rancangan Penelitian
Penelitian ini menggunakan metode eksperimental yang dilakukan di Laboratorium Teknik Mesin Fakultas Teknik Universitas Muhammadiyah Metro. Rancangan percobaan yang dilakukan pada penelitian ini adalah penelitian dengan tiga variabel perlakuan suhu yang berbeda. Pada penelitian ini perlakuan yang dilakukan secara berturut-turut adalah tanpa perlakuan suhu (T1), suhu $35^{\circ} \mathrm{C}(\mathrm{T} 2)$ dan $55^{\circ} \mathrm{C}$ (T3). Kegiatan penelitian dilakukan dengan menggunakan rancangan percobaan dengan distribusi variabel sebagai berikut :

1. T1 : Tanpa perlakuan suhu

2. T2 : Perlakuan dengan suhu $35^{\circ} \mathrm{C}$

3. T3 : Perlakuan dengan suhu $55^{\circ} \mathrm{C}$

\section{Alat dan Bahan}

Komponen utama dalam penelitian ini adalah reaktor digester sebagai tempat proses pencernaan anaerobik. Secara terperinci alat yang digunakan dalam penelitian dijelaskan dibawah ini.

1. Derigen kapasitas 10 liter yang terbuat dari plastik yang berfungsi sebagai digester untuk berlangsungnya proses fermentasi anaerobik

2. Selang dengan diameter $5 \mathrm{~mm}$ sebagai penyalur biogas

3. Bak untuk menampung air sebagai media penghantar suhu ke digester

4. Termokontrol yang berfungsi untuk mengontrol suhu secara otomatis

5. Termokopel yang berfungsi sebagai sensor suhu

6. Stabilizer yang berfungsi untuk menjaga agar tegangan listrik tetap stabil

7. Gelas ukur yang berfungsi untuk mengukur volume.

8. Tiang besi sebagai penyangga gelas ukur

9. Timbangan yang berfungsi untuk mengetahui berat benda/ bahan

10. Bor dan mata bor untuk membuat lubang pada derigen

11. Manometer $\mathrm{U}$ untuk mengukur tekanan biogas yang terjadi pada digester

12. Ember dan gayung untuk memasukkan bahan organik ke digester

13. Pisau dan gunting yang berfungsi untuk memotong bahan

14. Rol kabel untuk mengalirkan arus listrik

15. Lem untuk merekatkan sambungan dan untuk mengatasi kebocoran 
16. Alat tulis untuk mencatat berbagai data dari hasil percobaan.

\section{Hasil dan Pembahasan}

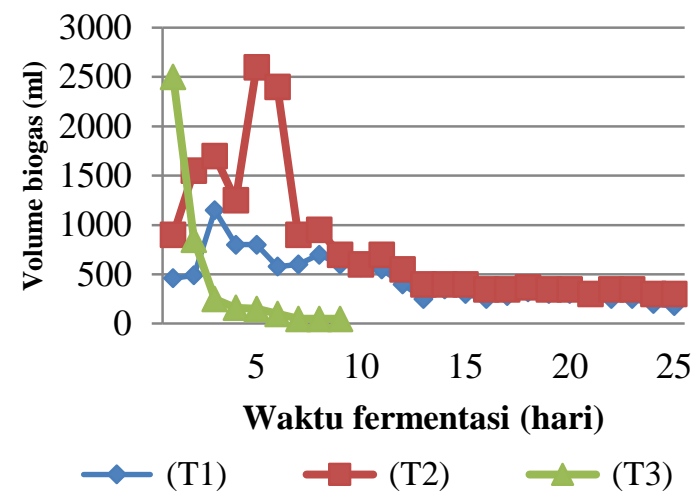

Gambar 2. Grafik volume biogas yang dihasilkan.

Gambar 2 diatas menjelaskan pengaruh suhu terhadap laju volume biogas yang dihasilkan pada masing-masing perlakuan. Volume biogas yang dihasilkan diamati setiap hari untuk mempelajari pengaruh perlakuan suhu pada produksi biogas dengan menggunakan bahan baku limbah kolam pembesaran ikan gurame.

Gambar 2 memperlihatkan bahwa perlakuan suhu sangat berpengaruh terhadap biogas yang dhasilkan. Subtrat limbah kolam pembesaran ikan gurame dengan perlakuan suhu $35^{\circ} \mathrm{C}$ menunjukkan hasil biogas paling banyak dibandingkan dengan subtrat tanpa perlakuan suhu maupun dengan perlakuan suhu $55^{\circ} \mathrm{C}$. Hasil nyata dan signifikan perlakuan suhu subtrat pada limbah kolam sangat memperlihatkan perbedaan hasil, dengan volume akumulasi biogas berturutturut pada perlakuan T1, T2 dan T3 adalah $11.210 \mathrm{ml}, 19.370 \mathrm{ml}$ dan $4.210 \mathrm{ml}$.

Hasil terbanyak biogas yang dihasilkan pada perlakuan suhu $35^{\circ} \mathrm{C}$ dimungkinkan terjadi karena proses degradasi senyawa komplek yang terkandung pada limbah organik terjadi lebih cepat dan kontinyu. Suhu $35^{\circ} \mathrm{C}$ merupakan suhu optimun pada perlakuan kondisi mesofilik. Hal ini sesuai dengan pernyataan (Agustina, 2011) bahwa operasi fermentasi anaerobik dilakukan pada temperature mesofilik, yaitu pada suhu 28 $45^{\circ} \mathrm{C}$ dengan rentan suhu optimum $35-40^{\circ} \mathrm{C}$.

Sedangkan pada perlakuan subtrat pada suhu $55^{\circ} \mathrm{C}$ menghasilkan hasil biogas paling sedikit, tetapi proses pembentukan biogas yang sangat cepat. Hal ini didapatkan dari hasil biogas yang mencapai volume $2.500 \mathrm{ml}$ pada hari pertama perlakuan. Pada perlakuan suhu $55^{\circ} \mathrm{C}$ proses pembentukan biogas mulai berhenti pada hari ke-10 dengan hasil yang terus menurun pada tujuh hari terakhir. Perlakuan suhu $55^{\circ} \mathrm{C}$ mengakibatkan subtrat akan terdegradasi lebih cepat dan memudahkan difusi bahan terlarut, sehingga pembentukan gas akan lebih cepat. Hal ini sesuai dengan pernyataan (Metchal dan Eddy dalam Khori Ex Indarto, 2010) bahwa suhu tinggi digunakan untuk penghancuran dan produksi tinggi ( $\mathrm{m} 3$ gas $/ \mathrm{m} 3$ bahan per hari) serta waktu retensi pendek dan bebas dari desinfektan.

Subtrat tanpa perlakuan suhu menunjukkan hasil biogas yang cukup baik dibandingkan dengan subtrat dengan perlakuan suhu $50^{\circ} \mathrm{C}$ yaitu menghasilkan akumulasi biogas sebanyak 11.210 ml. pada subtrat ini subtrat dibiarkan tanpa dilakukan perlakuan suhu dan hanya mengikuti suhu ruangan yang fluktuatif berkisar $26-32^{\circ} \mathrm{C}$

Proses pencernaan anaerobik sangat peka terhadap perubahan suhu (Wellinger dan Lindeberg dalam Khori Ex Indarto, 2010). Perubahan suhu yang mendadak didalam reaktor akan memperlambat proses produksi biogas. Dari hasil penelitian yang dilakukan, akumulasi hasil biogas selama 25 hari penelitian dijelaskan pada grafik dibawah ini.

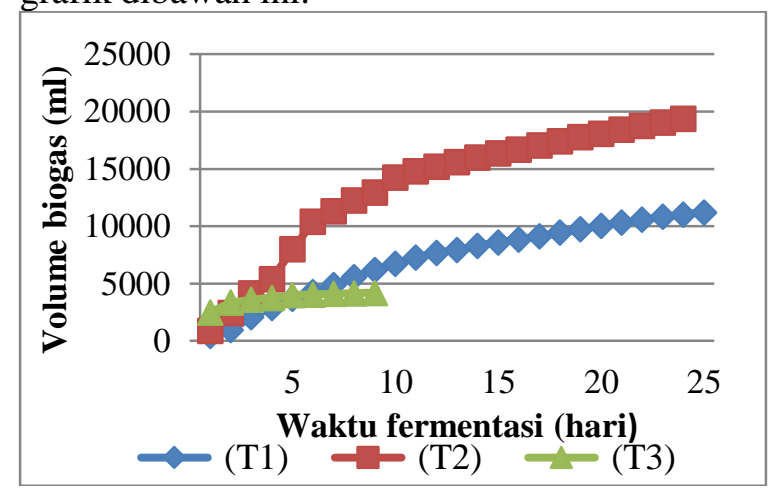

Gambar 3. Grafik pengaruh perlakuan suhu terhadap akumulusi hasil biogas.

Dapat dilihat pada gambar 3 diatas bahwa subtrat tanpa perlakuan suhu dan subtrat dengan perlakuan suhu $35^{\circ} \mathrm{C}$ mampu memproduksi biogas sampai hari ke-25, sedangkan subtrat dengan perlakuan suhu $55^{\circ} \mathrm{C}$ mampu memproduksi biogas sampai hari ke-10.

Grafik akumulasi biogas diatas juga menjelaskan bahwa perlakuan suhu pada subtrat limbah kolam pembesaran ikan gurame sangat berpengaruh terhadap produksi biogas pada 
pencernaan anaerob. Perlakuan suhu $35^{\circ} \mathrm{C}$ merupakan perlakuan suhu yang paling ideal.

Dari Gambar 3 dapat dilihat pada perlakuan suhu $35^{\circ} \mathrm{C}$ produksi puncak biogas dapat terjadi pada hari ke-2 sampai hari ke-6 dengan produksi biogas diatas $1.500 \mathrm{ml}$ per hari, sedangkan untuk subtrat tanpa perlakuan suhu produksi puncak hanya terjadi pada hari ke-3 dan perlakuan suhu $55^{\circ} \mathrm{C}$ terjadi pada hari pertama. Perbandingan hasil total produksi biogas dapat dilihat pada gambar 4 dibawah ini.

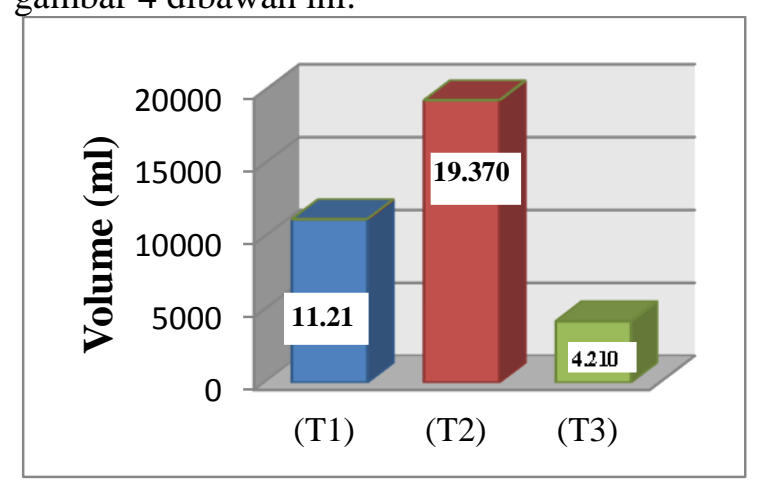

Gambar 4. Diagram perbandingan hasil produksi biogas terhadap perlakuan suhu

Gambar 4 diatas memperlihatkan perbedaan hasil biogas yang cukup signifikan antar perlakuan pada subtrat. Hasil terbanyak diperoleh pada subtrat dengan perlakuan suhu $35^{\circ} \mathrm{C}$ dengan total produksi sebanyak $19.370 \mathrm{ml}$ lebih tinggi dari subtrat tanpa perlakuan suhu dan perlakuan suhu $55^{\circ} \mathrm{C}$ yang masing-masing memproduksi 11.210 $\mathrm{ml}$ dan $4.210 \mathrm{ml}$. Dari perbandingan ini dapat dianalisa bahwa perlakuan suhu berpengaruh besar terhadap kuantitas biogas yang dihasilkan.

\section{Kesimpulan}

Produksi biogas dengan perlakuan subtrat tanpa perlakuan suhu menghasilkan total akumulasi hasil biogas $11.210 \mathrm{ml}$, laju aliran sebesar 448,4 $\mathrm{ml} / \mathrm{hari}$ dan potensi biogas $1.401,25 \mathrm{ml} / \mathrm{liter}$ bahan baku, sedangkan perlakuan kondisi suhu mesofilik $35^{\circ} \mathrm{C}$ menghasilkan biogas 19.310 , laju aliran 774,8 $\mathrm{ml} /$ hari dan potensi biogas $2.421,25 \mathrm{ml} /$ liter. Untuk perlakuan kondisi suhu termofilik $55^{\circ} \mathrm{C}$ menghasilkan biogas $4.210 \mathrm{ml}$, laju aliran 168,4 $\mathrm{ml} /$ perhari dan potensi $520 \mathrm{ml} /$ liter bahan baku pada tekanan biogas yang sama pada semua perlakuan yaitu $101.570,25 \mathrm{~N} / \mathrm{m}^{2}$. Dari hasil keseluruan bahwa yang paling baik adalah pada kondisi suhu mesofilik.

\section{DAFTAR PUSTAKA}

1. Chang, Raymond. 2005. Kimia Dasar: Konsep-Konsep Inti Jilid 1 Edisi Ketiga. Jakarta: Erlangga.

2. Indarto, Khori Ex. 2010. Produksi Biogas Limbah Cair Industri Tapioka Melalui Peningkatan Suhu dan Penambahan Urea pada Perombakan Anaerob.

3. Kaharudin dan Farida Sukmawati M. 2010. Petunjuk Praktis Manajemen Umum Limbah Ternak untuk Kompos dan Biogas. Kementerian Pertanian: Balai Pengkajian Teknologi Pertanian NTB.

4. Kementerian Pertanian, Kehutanan dan Perikanan. 2008. Buku Panduan Biomassa Asia.

5. Rahayu, S.P, Sri dan Masirah, S.Pi. 2014. Jurus Sakti Pembesaran Lele Sangkurian di Kolam Terpal. Jakarta: Andi.

6. Sani, Berlin. 2014. Budidaya Ikan Gurami. Yogyakarta: Dafa Publising.

7. Suriawiria, Unus. 2003. Mikrobiologi Air dan Dasar-Dasar Pengolahan Buangan Secara Biologis. Bandung: PT. Alumni.

8. Wahyono, Edi Hendras dan Nano Sudarmo. 2012. Biogas Energi Ramah Lingkungan. Bogor : Developing Collaborative Manajement of Cibodas Biosphere Reserve West Java.

9. Waskito, Didit. 2011. Analisa Pembangkit Listrik Tenaga Biogas dengan Pemanfatkan Kotoran Sapi di Kawasan Usaha Peternakan Sapi. Tesis tidak diterbitkan. Salemba: Fakultas Teknik Program Magister Teknik Manajemen Energi dan Ketenagalistrikan UI Salemba. 